\title{
PENGARUH GAYA KEPEMIMPINAN PARTISIPATIF DAN KOMUNIKASI TERHADAP KINERJA APARATUR SERTA DAMPAKNYA TERHADAP KUALITAS PELAYANAN PUBLIK
}

\author{
${ }^{1}$ Rizki Pradina Nugraha, ${ }^{2}$ Lalan Soeherlan S, ${ }^{3}$ Aceng Jarkasih \\ (1)Mahasiswa Magister Ilmu Administrasi, Universitas Majalengka, Jawa Barat, Indonesia \\ (2)(3)Dosen Magister Ilmu Administrasi, Pascasarjana Universitas Majalengka, Jawa Barat, Indonesia \\ e-mail korespondensi: pradinarizky6@gmail.com
}

Disubmit Agustus 2020 , Diterima September 2020 , Diterbitkan Oktober 2020

Submitted August 2020, Accepted September 2020, Published October 2020

Penulis koresponden

Jurnal DIALOGIKA

Manajemen dan Administrasi diterbitkan oleh Program Studi Administrasi Publik Pascasarjana Universitas Majalengka

\begin{abstract}
The performance of public services has a huge influence on the quality of people's lives. The factors that influence public services in this study were identified from the aspects of employee performance, participatory communication and leadership. This type of research used in this research is descriptive verification research. Data collection techniques in this study using survey techniques and data sources in this study are primary and secondary data. The data analysis technique in this study used the path analysis method. The results of descriptive research indicate that participatory leadership, communication, employee performance and service quality are in the sufficient category, so it is necessary to increase their role in order to improve the quality of public services. The results of hypothesis testing have proven that there is an influence between participatory leadership style and communication, both partially and simultaneously, which have a positive effect on employee performance. The results of other hypothesis testing prove that employee performance has a positive and significant effect on the quality of public services.
\end{abstract}

Keywords: leadership, communication, employee performance and public service quality Abstrak

Kinerja pelayanan publik sangat besar pengaruhnya terhadap kualitas kehidupan masyarakat. Faktor-faktor yang berpengaruh pada pelayanan public pada penelitian ini diidentifikasi dari aspek kinerja pegawai, komunikasi dan kepemimpinan yang partisipatif. Jenis penelitian yang digunakan dalam penelitian ini adalah penelitian deskriptif verifikatif. Teknik pengambilan data pada penelitian ini menggunakan teknik survey dan sumber data pada penelitian ini adalah data primer dan sekunder. Teknik analisis data pada penelitian ini menggunakan metode analisis jalur. Hasil penelitian deskriptif menunjukkan bahwa kepemimpinan partisipatif, komunikasi, kinerja pegawai dan kualitas pelayanan berada pada kategori cukup, sehingga perlu dilakukan peningkatan perannya dalam rangka meningkatkan kualitas pelayanan public. Hasil pengujian hipotesis telah membuktikan terdapat pengaruh antara gaya kepemimpinan partisipatif dan komunikasi baik secara parsial maupun simultan berpengaruh positif terhadap kinerja pegawai. Hasil pengujian hipotesis lainnya terbukti bahwa kinerja pegawai berpengaruh positif dan signifikan terhadap kualitas pelayanan public.

Kata kunci: Kepemimpinan, komunikasi, kinerja dan kualitas pelayanan public.

\section{PENDAHULUAN}

Perilaku kepemimpinan memiliki kecenderungan pada dua hal yaitu konsiderasi atau hubungan dengan bawahan dan struktur inisiasi atau hasil yang dicapai. Kecenderungan 
kepemimpinan menggambarkan hubungan yang akrab dengan bawahan misalnya bersikap ramah, membantu dan membela kepentingan bawahan, bersedia menerima konsultasi bawahan dan memberikan kesejahteraan. Kecenderungan seorang pemimpin memberikan batasan antara peranan pemimpin dan bawahan dalam mencapai tujuan, memberikan instruksi pelaksanaan tugas (kapan, bagaimana dan hasil apa yang akan dicapai). Suatu gaya pemimpin atau manajer dalam organisasi merupakan penggambaran langkah kerja bagi karyawan yang berada di bawahnya.

Faktor penting yang menentukan kinerja karyawan dan kemampuan organisasi beradaptasi dengan perubahan lingkungan menurut Bass et al. (2003:112), Locander et al. (2002:201), serta Yammarino et al. (1993:67) adalah kepemimpinan (leadership). Kepemimpinan menggambarkan hubungan antara pemimpin (leader) dengan yang di pimpin (follower) dan bagaimana seorang pemimpin mengarahkan follower akan menentukan sejauh mana follower mencapai tujuan atau harapan pimpinan (Locander et al 2002; Yammarino et al 1993). Pemimpin mengembangkan dan mengarahkan potensi dan kemampuan bawahan untuk mencapai bahkan melampaui tujuan organisasi (Dvir et al 2002:43).

Sehubungan dengan adanya perbedaan dalam memimpin suatu organisasi, antara pemimpin satu dengan yang lain berbeda dalam sifat, kebiasaan, temperamen, watak dan kepribadiannya, sehingga tingkah laku dan gayanya tentunya tidak sama di antara mereka, karena itu akan muncul berbagai tipe atau gaya kepemimpinan yang akan dijalankan setiap pemimpin dalam mencapai tujuan organisasi. Sehingga untuk mengetahui efektifitas pimpinan, maka tergantung pada tanggapan para pengikutnya atas perilaku pemimpin yang bersangkutan pada saat mereka saling berinteraksi dengan melihat implementasi gaya kepemimpinan yang ada masih terdapat kelemahan-kelemahan yang mana dalam penerapan gaya kepemimpinan delegasi tersebut tidak efektif bilamana para bawahan memiliki kemampuan berpikir secara kritis, maka dalam mencapai kesepakatan dalam pengambilan keputusan mengalami banyak hambatan sebab masingmasing bawahan dapat tetap mengutamakan pemikiran-pemikirannya yang mereka anggap sudah sesuai. Gaya kepemimpinan yang dipakai akan menjadi faktor yang sangat berpengaruh dalam mencapi sasaran dan tujuan yang dikehendaki dan juga dapat mempengaruhi kinerja karyawan.

Komunikasi merupakan sarana untuk terjalinnya hubungan antar seseorang dengan orang lain, dengan adanya komunikasi maka terjadilah hubungan sosial, antara satu dengan yang lainnya saling membutuhkan, atau terjadinya interaksi timbal balik. Aktivitas komunikasi dalam kehidupan manusia mencakup spektrum yang sangat luas. Komunikasi menjadi wahana yang penting dalam menyampaikan pikiran, perasaan, ide-ide dan masalah kehidupan yang dihadapi seseorang kepada orang lain (Syafaruddin, 2005:150). Dalam perspektif manajemen komunikasi merupakan bagian integral dari alat manajemen dalam mencapai tujuan. Dengan kata lain komunikasi menjadi kunci yang menentukan efektif atau tidaknya manajemen.

Dalam konteks organisasi, interaksi yang dilakukan dalam pengelolaan sebuah organisasi oleh ketua/kepala terhadap personil yang ada memerlukan proses komunikasi yang efektif agar tujuan organisasi yang bermuara pada pencapaian tujuan organisasi dapat tercapai. Proses pertukaran pesan dari pengirim pesan (sender) kepada penerima pesan (receiver) agar muncul pengertian terhadap pesan yang akan diterima merupakan inti komunikasi. Pemimpin organisasi melaksanakan musyawarah melalui rapat rutin, pelaksanaan pengawasan dan evaluasi serta pengambilan keputusan dilaksanakan melalui komunikasi organisasi. Dalam perspektif manajemen, keberadaan komunikasi ditempatkan sebagai fasilitator di dalam aktivitas manajemen terutama dalam merencanakan, mengorganisasikan, melaksanakan, dan mengevaluasi memerlukan pertukaran pesan, fakta dan ide-ide serta pengalaman-pengalaman. Komunikasi yang baik akan mendorong 
mendapatkan pelaksanaan pekerjaan yang lebih baik.

Berdasarkan beberapa uraian masalah di atas, penulis tertarik untuk melakukan penelitian di Kecamatan Kadipaten, Kabupaten Majalengka dengan judul "Pengaruh Gaya Kepemimpinan Partisipatif dan Komunikasi terhadap Kinerja Aparatur Dampaknya terhadap Kualitas Pelayanan Publik di Desa Heuleut Kecamatan Kadipaten Kabupaten Majalengka" (Studi kasus pada pelayanan publik di bidang kependudukan).

\section{TINJAUAN PUSTAKA}

\section{a. Pengaruh Kepemimpinan Terhadap Kinerja Pegawai}

Kepemimpinan pada dasarnya mempunyai pokok pengertian sebagai sifat, kemampuan, proses, dan atau konsep yang dimiliki oleh seseorang sedemikian rupa sehingga ia diikuti, dipatuhi, dihormati orang lain dengan penuh keikhlasan melakukan perbuatan atau kegiatan yang dikehendaki pemimpin tersebut. Suatu organisasi akan berhasil atau gagal sebagaian besar ditentukan oleh kepemimpinan. Hal ini dapat dilihat bagaimana seorang pemimpin dalam bersikap dan bertindak. Cara bersikap dan bertindak dapat terlihat dari cara melakukan suatu pekerjaan. Suatu ungkapan mulia mengatakan bahwa pemimpinlah yang bertanggung jawab atas kegagalan pelaksanaan suatu pekerjaan. Hal ini merupakan ungkapan yang mendudukan posisi pemimpin dalam suatu instansi pemerintahan khususnya, pada posisi yang terpenting.

Sedangkan kinerja pegawai adalah merupakan hasil kerja yang dihasilkan oleh seorang pegawai dalam melaksanakan kerjanya. Hal ini juga berkaitan dengan kuantitas dan kualitas kerja yang dihasilkan. Artinya yaitu seberapa banyak pekerjaan yang dapat dilakukan dalam waktu yang telah ditentukan, dan apakah sesuai dengan mutu yang telah ditargetkan atau tidak. Tercapainya tujuan organisasi diharapkan tercapai pula tujuan individu para bawahan. Suatu organisasi akan berhasil mencapai tujuan dan sasarannya apabila semua komponen organisasi berupaya menampilkan kinerja yang optimal. Seorang pegawai akan efektif dalam melakukan pekerjaan apabila terdapat keyakinan dalam dirinya bahwa berbagai keinginan, kebutuhan, harapan dan tujuannya dapat tercapai. Dalam hal ini dapat dilihat bahwa peran dan tugas seorang pemimpin pada pemerintahan kecamatan Kadipaten Kabupaten Majalengka adalah berusaha untuk mempengaruhi para pegawainya dengan cara memotivasi dan komunikasi untuk terus bekerja secara efektif sesuai dengan waktu dan tujuan yang ingin dicapai. Dengan kata lain, efektif tidaknya pekerjaan yang dilakukan para pegawai, tergantung bagaimana cara atau sikap seorang pemimpin dalam memimpin. Atau apa-apa saja kegiatan yang perlu dilakukan agar semua pegawai mau dan rela mengikuti semua keinginan pemimpin tersebut demi mencapai tujuan organisasi.

\section{b. Pengaruh Komunikasi Organisasi terhadap Kinerja Pegawai}

Salah satu prinsip dalam manajemen dan organisasi adalah kerja sama. Kerjasama dapat dilaksanakan dengan baik apabila terjadi komunikasi dialogis antara manajer dan bawahan dan diantara seluruh pekerja yang melaksanakan kegiatan organisasi (Athoillah,2010). Dengan adanya respons, anggapan atau umpan balik yang diberikan oleh komunikan berarti pesan yang dikirim itu sudah sampai sehingga terjadi komunikasi dua arah (Athoillah,2010). Menurut Sopiah (2008:141) komunikasi adalah penyampaian atau pertukaran informasi dari pengirim kepada penerima, baik secara lisan, tertulis maupun menggunakan alat komunikasi. Pertukaran informasi yang terjadi diantara pengirim dan penerima tidak hanya dilakukan dalam bentuk lisan maupun tertulis, tetapi juga yang menggunakan alat komunikasi canggih. Pentingnya komunikasi dalam hubungannya dengan pekerjaan ditunjukkan oleh banyaknya waktu yang dipergunakan untuk berkomunikasi dalam pekerjaan.

Peran komunikasi dalam organisasi sangat penting dan menjadi porosnya berjalannya organisasi. Organisasi dapat berkembang dan maju dapat dilihat dari 
interaksi anggota organisasi dalam meyelesaikan pekerjaannya sehingga dapat mewujudkan kinerja pegawai yang optimal. Menurut Weick dalam Littlejhon dan Foss (2011:297) organisasi bisa bertahan hidup dan berkembang bila anggota organisasi terlibat dalam informasi yang mengalir dan adanya interaksi komunikasi. Sehingga aktivitas organisasi yang berjalan diperlukan suatu komunikasi dimana didalamnya terdapat informasi atau pesan yang saling mempengaruhi eluruh anggota organisasi untuk melakukan aktivitas. Aktivitas inilah yang dapat mempertahankan hidup organisasi untuk berkembang dan menghasilkan kinerja pegawai.

Redding dalam Muhammad (2005) berpendapat bahwa kepuasan komunikasi merupakan tingkat kepuasan seorang pegawai dalam mempersepsikan lingkungan komunikasi secara menyeluruh. Kepuasan komunikasi merupakan bagian dari kepuasna kerja yang merupakan rasa nyaman terhadap pesan, media dan hubungan terhadap lingkungan organisasi (Pace dan Faules, 2013:165). Kepuasan komunikasi berpengaruh terhadap kinerja pegawai dalam dimensi informasional atau relasional mempunyai dampak tinggi terhadap kinerja pegawai (Alsayed,2012).

\section{Hipotesis Penelitian}

Hipotesis merupakan jawaban sementara suatu penelitian yang mana kebenarannya perlu untuk diuji serta dibuktikan melalui penelitian. Dikatakan sementara, karena jawaban yang diberikan baru didasarkan pada teori yang relevan, belum didasarkan pada fakta-fakta empiris yang diperoleh melalui pengumpulan data. Dengan kata lain, hipotesis dapat juga dinyatakan sebagai jawaban teoritis terhadap rumusan masalah penelitian, belum jawaban yang empirik. (Sugiyono, 2005 : 70). Adapun hipotesis penelitian sebagai berikut :

1. Gaya kepemimpinan partisipatif dipersepsikan tinggi oleh responden.

2. Komunikasi yang dijalin saat ini dipersepsikan tinggi oleh responden.

3. Kinerja pegawai dipersepsikan tinggi oleh responden.

4. Kualitas pelayanan publik dipersepsikan tinggi oleh responden.
5. Terdapat pengaruh gaya kepemimpinan terhadap kinerja pegawai di Kecamatan Kadipaten Kabupaten Majalengka.

6. Terdapat pengaruh komunikasi terhadap kinerja pegawai di Kecamatan Kadipaten Kabupaten Majalengka.

7. Terdapat pengaruh gaya kepemimpinan dan komunikasi secara simultan terhadap kinerja pegawai di Kecamatan Kadipaten Kabupaten Majalengka.

8. Terdapat pengaruh kinerja pegawai terhadap kualitas pelayanan public di Kecamatan Kadipaten Kabupaten Majalengka

\section{METODE PENELITIAN}

Metode bagi suatu penelitian merupakan suatu alat di dalam pencapaian suatu tujuan untuk memecahkan suatu masalah. Menurut Sugiyono (2013:3) Metode penelitian adalah cara ilmiah untuk mendapatkan data dengan tujuan dan kegunaan tertentu. Metode yang digunakan adalah metode deskriptif dan verifikatif dilaksanakan melalui pengumpulan data di lapangan. Metode deskriptif menurut Sugiyono (2013:11) adalah metode penelitian yang bertujuan untuk menggambarkan, menjelaskan keadaan yang ada pada perusahaan berdasarkan fakta, sifat-sifat populasi berdasarkan datadata yang telah dikumpulkan kemudian disusun secara sistematis selanjutnya dianalisis untuk diambil kesimpulannya.

Pengolahan data diolah dan disajikan dalam bentuk tabel. Kemudian data yang diolah dari hasil pengumpulan kuisioner diberi bobot dalam setiap alternatif jawaban. Jawaban setiap item instrumen yang menggunakan skala Likert mempunyai gradasi dari sangat positif sampai sangat negatif. Dengan demikian, pertanyaan-pertanyaan yang digunakan untuk memperoleh data atau keterangan dari responden. Penelitian ini digunakan analisis regresi linier berganda, karena penelitian ini dilakukan untuk mengetahui pengaruh Gaya Kepemimpinan Partisipatif (X1) Komunikasi (X2) terhadap kinerja pegawai (Y). Menurut Sugiyono (2013:13) analisis regresi linier berganda adalah hubungan secara linier antara dua atau lebih variabel independen (X1, X2) dengan 
variabel dependen (Y) serta dampaknya terhadap kualitas pelayanan publik (Z).

\section{HASIL PENELITIAN DAN PEMBAHASAN}

Berdasarkan hasil penelitian yang telah dilakukan terhadap 30 responden, tentang kepimpinan partisipatif, komunikasi, kinerja pegawai dan kualitas pelayanan publik. Sebelum dilakukan analisis lebih lanjut, terlebih dahulu dilakukan pengkategorian kuesioner setiap masing masing variabel.

Tabel 1 Hasil Penelitian Deskriptif

\begin{tabular}{llccl}
\hline No & variabel & Mean & Persen & Kategori \\
\hline 1 & Kepemimpinan & 3.42 & 66.00 & Tinggi \\
& Partisipatif & & & \\
2 & Komunikasi & 3.23 & 64.67 & Sedang \\
3 & Kinerja & 3.27 & 65.33 & Sedang \\
& $\begin{array}{l}\text { Pegawai } \\
4\end{array}$ & Kualitas \\
& $\begin{array}{l}\text { Pelayanan } \\
\text { Publik }\end{array}$ & 3.33 & & Sedang \\
& \multicolumn{2}{c}{66.67} & \\
\hline Sumber : Data Primer yang diolah, 2020 &
\end{tabular}

Berdasarkan tabel 1 dari hasil analisis deskriptif terhadap variabel penelitian didapat hanya variabel kepemimpinan partisifatif yang termasuk pada kategori tinggi, sementara variabel komunikasi, kinerja pegawai dan kualitas pelayanan public termasuk pada kategori sedang. Hasil penelitian ini membuktikan secara empiris bahwa faktor kepemimpinan sudah baik, namun masalah komunikasi, kinerja dan kualitas pelayanan public perlu dibangun lebih baik lagi mengingat tingkat ketercapaiannya masih tergolong sedang. Hasil penelitian verifikatif dengan menggunakan analisis jalur dapat dilihat pada gambar berikut ini.

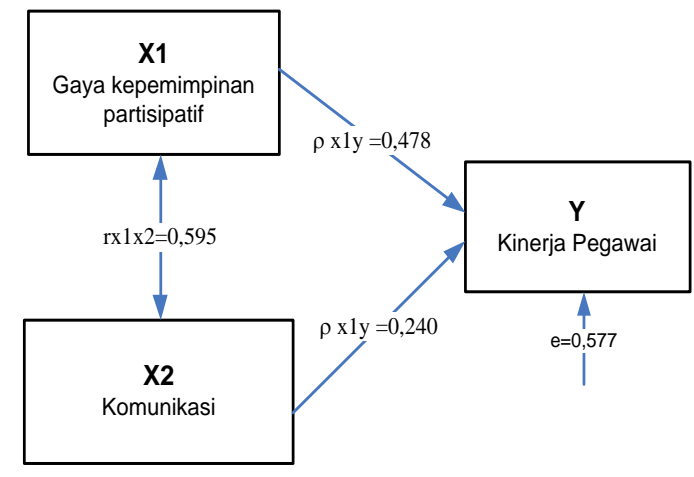

Gambar 1 Hasil Analisis terhadap Struktur I Sumber : Data Primer yang diolah, 2020
Berdasarkan gambar di atas, maka dapat dijelaskan mengenai persamaan garis analisis jalur sebagai berikut :

$(\mathrm{Y})=0,478\left(\mathrm{X}_{1}\right)+0,240\left(\mathrm{X}_{2}\right)+0,577$ (epsilon).

Kontribusi pengaruh yang diberikan

oleh variabel gaya kepemimpinan partisipatif terhadap kinerja pegawai secara langsung sebesar $0,478^{2} \times 100 \%=22,48 \%$. Sementara untuk pengaruh komunikasi secara langsung terhadap kinerja pegawai sebesar $0,240^{2}$ x $100 \%=5,76 \%$.

Kontribusi pengaruh tidak langsung dari gaya kepemimpinan partisipatif terhadap kinerja pegawai melalui komunikasi sebesar $0,478 \times 0,595 \times 0,240$ $\mathrm{x} 100 \%=6,82 \%$, begitupun dengan pengaruh tidak langsung dari komunikasi terhadap kinerja pegawai melalui gaya kepemimpinan partisipatif sebesar 6,82\%. Kontribusi total pengaruh yang diberikan oleh gaya kepemimpinan partisipatif terhadap kinerja pegawai sebesar 22,48\% + $6,82 \%=29,3 \%$; dan total pengaruh komunikasi terhadap kinerja pegawai sebesar $5,76 \%+6,82 \%=12,58 \%$. Total pengaruh secara simultan yang diberikan oleh variabel gaya kepemimpinan partisipatif dan komunikasi terhadap kinerja pegawai sebesar $29,3 \%+12,58 \%=$ $41,88 \%$ dan sisanya sebesar $58,12 \%$ dipengaruhi oleh faktor lain diluar penelitian.

\section{Analisis Struktur II (kinerja pegawai terhadap Kualitas pelayanan publik)}

Analisis terhadap kontribusi pengaruh yang diberikan oleh kinerja pegawai terhadap kualitas pelayanan publik dapat diketahui dari nilai koefisien determinasi dari variabel tersebut, sebagaimana dijelaskan pada tabel sebagai berikut :

Tabel 2 Koefisien Determinasi Y dan Z Model Summary

\begin{tabular}{llrrr}
\hline Model & $\mathrm{R}$ & $\begin{array}{c}\mathrm{R} \\
\text { Square }\end{array}$ & $\begin{array}{c}\text { Adjusted } \\
\text { R Square }\end{array}$ & $\begin{array}{c}\text { Std. Error } \\
\text { of the } \\
\text { Estimate }\end{array}$ \\
\hline 1 & $.788^{\mathrm{a}}$ & .620 & .617 & 5.12178 \\
\hline
\end{tabular}

a. Predictors: (Constant), kinerja pegawai_Y

Sumber : Data Primer yang diolah, 2020

Tabel di atas, menunjukkan bahwa kinerja pegawai terhadap kualitas pelayanan publik memiliki nilai koefisien determinasi sebesar 0,620. Hasil ini mengindikasikan bahwa prestasi belajar 
memiliki kemampuan dalam menjelaskan kualitas pelayanan publik sebesar 0,620 dan sisanya sebesar 0,38 dijelaskan oleh faktor lain di luar model yang diteliti. Untuk lebih lengkapnya dapat diuraikan pada gambar sebagai berikut :

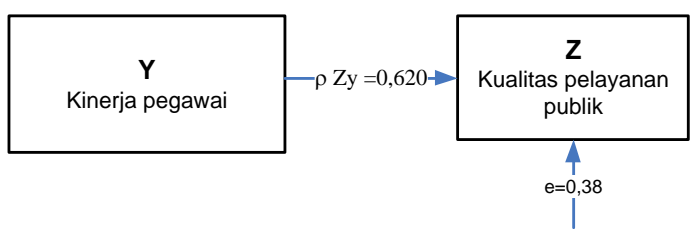

Gambar 2 Hasil Analisis terhadap Struktur II Sumber : Data Primer yang diolah, 2020

Berdasarkan Gambar di atas, maka dapat dijelaskan mengenai persamaan garis analisis jalur sebagai berikut :

$(\mathrm{Z})=0,620(\mathrm{Y})+0,38$ (epsilon).

Kontribusi pengaruh yang diberikan oleh variabel kinerja pegawai terhadap kualitas pelayanan publik sebesar $0,788^{2} \mathrm{x}$ $100 \%=62,09 \%$, dan sisanya sebesar $38,09 \%$ dipengaruhi oleh faktor lain diluar model penelitian. Hasil tersebut konsiten dengan nilai koefisien determinasi di atas. Adapun mengenai hasil analisis terhadap keseluruhan model penelitian diuraikan sebagai berikut :

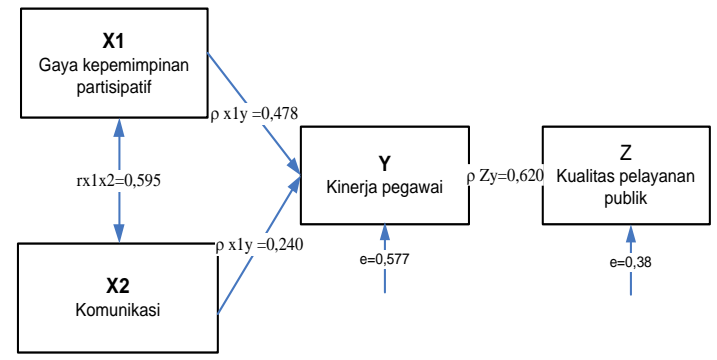

Gambar 3 Hasil Analisis Jalur

Sumber : Data Primer yang diolah, 2020

\section{Uji Hipotesis}

Setelah diketahui bahwa ketiga variabel telah memiliki validitas, reliabilitas dan berdistribusi normal, selanjutnya dilakukan pengujian hipotesis. Pengujian hipotesis dilakukan pada data variabel gaya kepemimpinan partisipatif dan komunikasi terhadap kinerja pegawai dan diuji menggunakan uji statistik dua pihak dengan cara membandingkan antara t-hitung dengan t-tabel sebagai berikut:

\section{Hipotesis 1 :}

$\mathrm{H}_{0}: \quad$ : Gaya kepemimpinan partisipatif $\rho_{\mathrm{yx} 1}=0 \quad$ tidak berpengaruh terhadap kinerja

$\begin{array}{cl} & \text { pegawai } \\ \mathrm{H}_{1}: & : \quad \begin{array}{l}\text { Gaya kepemimpinan partisipatif } \\ \rho_{\mathrm{yx} 1 \neq 0} \neq 0 \text { berpengaruh terhadap } \\ \text { pegawai }\end{array}\end{array}$

Dengan kriteria uji : tolak $\mathrm{H}_{0}$ jika Sig. $<0.05$ atau thitung $>$ t tabel.

Hipotesis 2:

$\mathrm{H}_{0}: \rho_{\mathrm{yx} 2}=0 \quad: \quad \begin{array}{r}\text { Komunikasi tidak } \\ \text { berpengaruh terhadap } \\ \text { kinerja pegawai }\end{array}$
$\mathrm{H}_{1}: \rho_{\mathrm{yx} 2} \neq 0: \begin{aligned} & \text { Komunikasi berpengaruh } \\ & \text { terhadap } \\ & \text { pegawai }\end{aligned}$

Dengan kriteria uji : tolak $\mathrm{H}_{0}$ jika Sig. $<0.05$ atau $\mathrm{t}$ hitung $>\mathrm{t}$ tabel.

Tabel 3 Pengujian Hipotesis secara Parsial

\begin{tabular}{lcccc}
\hline Strukt & $\begin{array}{c}\text { Koef. } \\
\text { jalur }\end{array}$ & $\begin{array}{c}\text { t } \\
\text { hit }\end{array}$ & Sign. & $\begin{array}{c}\text { Kesim- } \\
\text { pulan }\end{array}$ \\
\hline$\rho_{\mathrm{yx} 1}$ & 0,478 & 5,102 & 0.001 & $\begin{array}{c}\text { Ho } \\
\text { ditolak } \\
\text { Ho }\end{array}$ \\
$\rho_{\mathrm{yx} 2}$ & 0,240 & 2,568 & 0.000 & $\begin{array}{c}\text { Ho } \\
\text { ditolak }\end{array}$ \\
\hline
\end{tabular}

Sumber : Data Primer yang diolah, 2020

Hasil perhitungan pertama menunjukkan nilai $t$ hitung untuk variabel gaya kepemimpinan partisipatif sebesar 0,478 dengan tingkat signifikansi $(\alpha)=5 \%$. diperoleh nilai Sign. $=0.000$. Sesuai dengan hasil yang diperoleh yaitu Sign. $(0.000)<$ 0.05 serta t-hitung $(5,102)>$ t-tabel $(1,983)$ maka $\mathbf{H}_{\mathbf{0}}$ ditolak dan $\mathbf{H}_{\mathbf{1}}$ diterima, dengan demikian dapat disimpulkan bahwa gaya kepemimpinan partisipatif memiliki pengaruh terhadap kinerja pegawai. Hasil perhitungan kedua menunjukkan nilai $t$ hitung untuk variabel komunikasi sebesar 0,240 dengan tingkat signifikansi $(\alpha)=5 \%$. diperoleh nilai Sign. $=0.000$. Sesuai dengan hasil yang diperoleh yaitu Sign. $(0.000)<$ 0.05 serta t-hitung $(2,568)>$ t-tabel $(1,983)$ maka $\mathbf{H}_{0}$ ditolak dan $\mathbf{H}_{1}$ diterima, dengan demikian dapat disimpulkan bahwa komunikasi memiliki pengaruh terhadap kinerja pegawai.

\section{Hipotesis 3 :}

$\mathrm{H}_{0}: \operatorname{\rho yx} 1=$ pyx2 $=0$

$\mathrm{H}_{1}: \operatorname{\rho yx} 1 \neq$ $\rho \mathrm{yx} 2 \neq 0$
Gaya kepemimpinan partisipatif dan komunikasi tidak berpengaruh terhadap kinerja pegawai Gaya kepemimpinan partisipatif dan komunikasi 
berpengaruh terhadap kinerja pegawai

Dengan kriteria uji : tolak $\mathrm{H}_{0}$ jika Sig. $<0.05$ atau $\mathrm{F}$ hitung $>\mathrm{F}$ Tabel

Tabel 4 Pengujian Hipotesis secara Simultan

\begin{tabular}{lcccc}
\hline Strukt & $\begin{array}{c}\text { Koef. } \\
\text { determ }\end{array}$ & $\begin{array}{c}\text { F } \\
\text { hitung }\end{array}$ & Sign. & $\begin{array}{c}\text { Kesim- } \\
\text { pulan }\end{array}$ \\
\hline$\rho_{\mathrm{yx} 1 ;}$ & 0,620 & 168,229 & 0.000 & $\begin{array}{l}\text { Ho } \\
\text { ditolak }\end{array}$ \\
$\rho_{\mathrm{yx} 2}$ & & & & \\
\hline
\end{tabular}

Sumber : Data Primer yang diolah, 2020

Dari tabel di atas, terlihat bahwa $\mathrm{F}$ hitung adalah 168,229 dengan nilai Sign. = 0,000 , lebih kecil dari $0,05(\alpha)$, dengan demikian $\mathbf{H}_{0}$ ditolak dan $\mathbf{H}_{1}$ diterima sehingga dapat disimpulkan bahwa gaya kepemimpinan partisipatif dan komunikasi berpengaruh terhadap kinerja pegawai.

Hipotesis 4 :

$\mathrm{H}_{0}: \rho_{\mathrm{zy}}=0 \quad$ : Kinerja pegawai tidak berpengaruh terhadap kualitas pelayanan publik

$\mathrm{H}_{1}: \rho_{\text {zy }} \neq 0 \quad$ : $\quad$ Kinerja pegawai berpengaruh terhadap kualitas pelayanan publik

Dengan kriteria uji : tolak $\mathrm{H}_{0}$ jika Sig. $<0.05$ atau thitung $>\mathrm{t}$ tabel.

Tabel 5 Pengujian Hipotesis diparsialkan

\begin{tabular}{lllll}
\hline Strukt & $\begin{array}{c}\text { Koef. } \\
\text { determ }\end{array}$ & $\begin{array}{c}\text { t } \\
\text { hitung }\end{array}$ & Sign. & $\begin{array}{c}\text { Kesim- } \\
\text { pulan }\end{array}$ \\
\hline$\rho_{\mathrm{Zy}}$ & 0,788 & 12,97 & 0.000 & $\begin{array}{l}\text { Ho } \\
\text { ditolak }\end{array}$ \\
\hline
\end{tabular}

Sumber : Data Primer yang diolah, 2020

Hasil perhitungan keempat menunjukkan nilai t-hitung untuk variabel kinerja pegawai terhadap kualitas pelayanan publik sebesar 0,788 dengan tingkat signifikansi $(\alpha)=5 \%$. diperoleh nilai Sign. $=0.000$. Sesuai dengan hasil yang diperoleh yaitu Sign. $(0.000)<0.05$ serta thitung $(12,97)>$ t-tabel $(1,983)$ maka $\mathbf{H}_{\mathbf{0}}$ ditolak dan $\mathrm{H}_{\mathbf{1}}$ diterima, dengan demikian dapat disimpulkan bahwa kinerja pegawai memiliki pengaruh terhadap kualitas pelayanan publik.

\section{Pembahasan Hasil Penelitian}

Setelah seluruh data dalam penelitian ini diuraikan, maka selanjutnya akan dilakukan pembahasan dari hasil data yang telah diolah tersebut. Berdasarkan data yang diperoleh dari penyebaran kuesioner yang dilakukan seluruh pegawai di Kecamatan Kadipaten Kabupaten Majalengka. Maka dapat diketahui bahwa tanggapan responden yang tertinggi untuk variabel kepemimpinan partisipatif terdapat pada dimensi kemampuan dalam memecahkan konflik dengan rata-rata 3.42 Nilai tanggpan ini berada pada kategori tinggi. Hal ini sama dengan hasil wawancara dengan beberapa staf pegawai di Kecamatan Kadipaten bahwa kebiasan pimpinan disini adalah selalu melakukan menjaga hubungan baik dengan para staf pegawai dan memberikan tugasnya sesuai dengan tanggungjawab setiap bidang pekerjaannya. Faktor kedua pimpinan selalu mengutamakan dan memberikan pesan kepada seluruh staf pegawai untuk bekerja secara team work agar pekerjaan dapat diselesaikan secara tertib dan terencana serta dapat mengurangi tingkat kesalahan secara personal. Faktor ketiga pemimpin selalu respon terhadap perubahan organisasi dari kondisi lingkungan yang tidak pasti, sehingga setiap permasalahan yang muncul dapat dengan mudah di atasi. Oleh karena itu pendapat dari para pegawai yang telah berhasil diwawancara menunjukkan bahwa peran pemimpin yang menguatkan terhadap sifat pemimpin partisipatif adalah terkait dengan kemampuan pemimpin dalam berkoordinasi. Dari hasil penyebaran kuesioner dan kesimpulan dari hasil kesimpulan wawancara dapat ditarik kesimpulan bahwa untuk dimensi kemampuan berkoordinasi yang telah biasa dilakukan oleh pimpinan perlu dipertahankan dari aspek kepemimpinan tipe partisipatif terhadap pola kepemimpinan dalam menkoordinasikan seluruh sumber daya organisasi yang dimiliki.

Hasil pengujian hipotesis terhadap pengaruh gaya kepemimpinan partisipatif sebagai variabel bebas dengan kinerja pegawai sebagai variabel terikat. Berdasarkan hasil analisis tersebut, maka dapat disimpulkan bahwa hipotesis alternatif yang dimunculkan diterima, yakni terdapat hubungan yang linier antara persepsi gaya kepemimpinan partisipatif dengan kinerja pegawai. Artinya semakin tinggi penilaian pegawai terhadap 
pemimpin dalam organisasi yang menggunakan gaya kepemimpinan partisipatif maka akan semakin tinggi kinerja pada organisasinya. Hasil penelitian ini juga terdapat pada penelitian-penelitian sebelumnya dengan variabel yang sama, maupun terdapat tambahan variabel lain. Pada penelitian Rukmana (2016) dengan hasil yang menunjukkan bahwa adanya hubungan yang signifikan antara gaya kepemimpinan partisipatif dengan work engagement. Sejalan dengan itu, Penelitian yang dilakukan Andre Setiawan (2017) menyatakan gaya kepemimpinan partisipatif yang telah diujikan terhadap kinerja karyawan melalui motivasi dan kepuasan kerja terbukti berpengaruh positif dan signifikan.

Berdasarkan data yang diperoleh dari penyebaran kuesioner yang dilakukan seluruh pegawai di Kecamatan Kadipaten Kabupaten Majalengka. Maka dapat diketahui bahwa tanggapan responden yang tertinggi untuk variabel komunikasi terdapat pada dimensi sikap positif dengan rata-rata 3,47 dan Nilai tanggapan ini berada pada kategori tinggi. Hal ini sama dengan hasil wawancara dengan Camat di Kecamatan Kadipaten bahwa kebiasaan yang telah menjadi budaya di Kantor Kecamatan Kadipaten adalah mengenai sikap positif terutama dalam menjaga transparansi dari setiap aktifitas yang dilakukan oleh seluruh unsur kepegawaian di Kecamatan Kadipaten. Lebih lanjut pernyataan tersebut diperjelas mengenai keterbukaan terutama dalam penyampaian informasi baik tentang pekerjaan maupun tentang informasi tentang karir pegawai maupun bidang pegawai yang menjadi tugas dan tanggungjawabnya. Selain itu keterbukaan tersebut bisa dilihat dari kegiatan rapat maupun diskusi yang dilakukan antar pimpinan dengan para sfat pegawainya serta keterbukaan dalam menguraikan visi dan misi menjadi tujuan organisasi yang akan dicapai. Oleh karena itu dengan persepsi responden terhadap tingginya penilaian keterbukaan yang didasarkan dari hasil penelitian sebaiknya dimensi tersebut untuk terus dipertahankan oleh seluruh jajaran pegawai di lingkungan Kantor Kecamatan Kadipaten, karena memberikan dampak positif terhadap iklim dan budaya kerja, selain itu dengan aktifnya komunikasi yang dilakukan maka pegawai dapat mempermudah dalam sharring knowledge satu sama lainnya terutama dalam menghadapi kendala-kendala yang dihadapi para pegawai dalam melaksanakan tugas bidang masing-masing.

Hasil pengujian hipotesis yang pertama menunjukan pengaruh komunikasi internal terhadap kinerja karyawan menunjukkan nilai koefisien jalur sebesar 0,240 nilai t sebesar 2,568 berarti nilai lebih besar dari $t$ tabel 1,96. Hal ini berarti komunikasi memiliki pengaruh positif dan signifikan terhadap kinerja pegawai. Seperti yang diketahui komunikasi sangat dibutuhkan dalam organisasi. Menurut Thayer (dalam Hardjana, 2016:129) sistem ini dibutuhkan oleh setiap organisasi untuk menjalankan fungsi-fungsi internal dan eksternal organisasi, yang berpengaruh pada kemampuan organisasi untuk mencapai tujuan dan memelihara perkembangan. Untuk organisasi yang besar, adalah penting untuk merancang sistem komunikasi yang sekaligus dapat membuat organisasi mampu menangani lingkungan, memelihara kerja fungsi internal, dan mengerti dan mampu melakukan perubahan yang dibutuhkan atau yang cocok. Selain itu peran seorang eksekutif atau disebut pimpinan harus dapat membangun, memelihara sebuah komunikasi yang efektif, serta meningkatkan produktivitas kerja anggota organisasi, pemimpin harus merumuskan dan menentukan arah tujuan organisasi.

Dari hasil kuesioner bisa diketahui cukup banyak pegawai masih tidak setuju dengan bahwa pimpinan mendengarkan saran dari pegawai direalisasikan, hal ini juga pasti setiap pemimpin memiliki kebijakan sendiri, untuk langsung menjalankan saran tersebut atau menimbang dahulu. Dalam hal ini pimpinan di Kecamatan Kadipaten masing kurang dalam membangun komunikasi internal antara pimpinan dan pegawai, pada doktrin tujuan organisasi misalnya pemimpin atau atasan tidak memiliki visi dan misi yang harus di sampaikan ke pegawai selain itu menekankan seberapa pentingnya orgaisasi di mata masyarakat juga masing sangat kurang. Padahal menurut Cutlip, center dan 
Broom (2009), (dalam Ruliana, 2016:102) menyatakan komunikasi internal yang berlangsung dalam organisasi didasarkan pada pernyataan visi dan pernyataan misi organisasi. Istilah pernyataan visi dan misi saling terkait erat, akan tetapi perbedaannya adalah jika visi (vision statements) memberikan gambaran tentang tujuan organisasi dalam pebgertian yang luas. Sementara pernyataan visi merupakan titik awal untuk menyusun pernyataan misi organisasi secara spesifik dan operasional. Pernyataan misi membantu karyawan menentukan prioritas dan tujuan sehingga organisasi berkomitmen untuk mencapai misi yang dinyatakan dalam pernyataan tersebut. Selain itu struktur organisasi sangat penting untuk dicantumkan di organisasi, di dalam skema organisasi akan terlihat penempatan tugas yang paling atas sampai dengan paling bawah. Struktur deskripsi organisasi ini menggambarkan informasi atau pesan kepemimpinan serta menunjukan hirarki hubungan wewenang dan tanggung jawab dari setiap unit, komunikasi pekerjaan yang saling berinteraksi satu sama lain melalui komunikasi guna mencapai tujuan organisasi yang telah ditetapkan.

Pengujian selanjutnya adalah mengenai pengaruh kepemimpinan partisipatif dan komunikasi terhadap kinerja pegawai. Hal ini dibuktikan dengan uji $\mathrm{F}$, dijelaskan bahwa dapat $\mathrm{F}$ hitung sebesar 168,229 dengan sig-f sebesar 0,000. Hal ini menunjukkan bahwa sig $F$ hitung jauh lebih kecil dari 0,05, maka Ha diterima dan menolak Ho. Dan mempunyai nilai koefisien determinasi $\mathrm{R}^{2}$ sebesar 0,620 yang mana dapat di artikan 62\% kinerja dipengaruhi oleh gaya kepemimpinan partisipatif dan komunikasi. Sedangkan sisanya sebesar $38 \%$ dipengaruhi oleh variabel lain yang tidak dimasukan dalam penelitian ini.

Hasil uji $\mathrm{F}$ di atas dibantu dengan dukungan penelitian sebelumnya oleh Sukmawati (2008) yang mendukung variabel komunikasi guna meningkatkan keaktifan pegawai dalam melakukan aktifitas sehingga dapat unsur kreatifitas dan inovasi dapat berkembang lebih baik, Mondiani (2012) mendukung pemimpin yang memiliki kematangan dan keluasan pandangan sosial dalam berorganisasi, Muizu (2014) mendukung bahwasanya motivasi seorang pemimpin adalah sebagai kontribusi seorang bawahan secara sukarelawan dalam pencapaian tujuan dan meningkatkan kinerja, Cahyono (2012) konsisten dalam kepimpinan dari sikap hubungan kerja sesama karyawan, karena pimpinan harus mempunyai perhatian tentang permasalahan yang ada dalam perorangan atau di dalam perusahaan. Dukungan serupa dari penelitian sebelumnya Puto (2013) pada Kanwil Ditjen Kekayaan Negara Suluttenggo dan Maluku Utara di Manado pengaruh yang positif terhadap tingkat kerja karyawan yaitu adanya hubungan baik antara bawahan dan atasan dalam menjalani tugas secara bersama-sama.

Berdasarkan dari hasil wawancara yang dilakukan dan pengamatan langsung dilapangan dapat disimpulkan bahwa terdapat faktor-faktor yang dapat menghambat jalannya kinerja pegawai yang pada akhirnya berdampak pada proses akuntabilitas kinerja dalam memberikan pelayanan public. Dari beberapa faktor tersebut dapat disimpulkan bahwa faktor yang menghambat proses pelayanan public pada kependudukan tidak hanya pada segi intern dalam diri pegawai dan kecamatan pada umumnya, akan tetapi lebih mengarah kepada alat yang tersedia sangat terbatas yang mengakibatkan turunnya kinerja pegawai dalam memberikan pelayanan sehingg akuntabilitas dalam diri pegawai akan berkurang. Hasil penelitian tersebut membuktikan bahwa variabel kinerja pegawai berpengaruh secara signifikan terhadap kualitas pelayanan publik atau dapat disimpulkan bahwa bahwa Ho ditolak dan $\mathrm{H} 1$ diterima.

Kinerja dalam sebuah organisasi merupakan salah satu unsur yang tidak dapat dipisahkan dalam suatu lembaga organisasi, baik itu lembaga pemerintahan maupun lembaga swasta. Kinerja berasal dari kata job performance atau actual performance yang merupakan prestasi kerja atau prestasi sesungguhnya yang dicapai seseorang. Kinerja adalah hasil atau tingkat keberhasilan seseorang secara keseluruhan selama periode tertentu di dalam melaksanakan tugas dibandingkan dengan 
berbagai kemungkinan, seperti standar hasil kerja, target atau sasaran atau kriteria yang telah ditentukan terlebih dahulu dan telah disepakati bersama.

\section{PENUTUP}

Berdasarkan data hasil penelitian mengenai analisis pengaruh gaya kepemimpinan partisipatif dan komunikasi terhadap kinerja pegawai serta dampaknya pada kualitas pelayanan public di Kecamatan Kadipaten Kabupaten Majalengka, maka dapat disimpulkan bahwa:

1. Hasil pengujian hipotesis telah membuktikan terdapat pengaruh antara gaya kepemimpinan partisipatif dengan kinerja pegawai. Pengujian membuktikan bahwa gaya kepemimpinan partisipatif memiliki pengaruh positif terhadap kinerja pegawai. Hal ini menunjukkan semakin baik gaya partisipatif yang diimplementasikan oleh setiap pimpinan, maka akan meningkatkan kinerja pegawai.

2. Hasil pengujian hipotesis telah membuktikan terdapat pengaruh antara komunikasi dengan kinerja pegawai. Pengujian membuktikan bahwa komunikasi memiliki pengaruh positif terhadap kinerja pegawai. Hal ini menunjukkan semakin baik komunikasi yang dilakukan oleh seluruh unsur yang ada di Kecamatan Kadipaten, maka akan meningkatkan kinerja pegawai.

3. Berdasarkan hasil dari analisis jalur secara simultan menunjukkan bahwa variabel gaya kepemimpinan partisipatif dan komunikasi berpengaruh signifikan terhadap kinerja pegawai. Hasil ini menunjukkan bahwa semakin tinggi gaya kepemimpinan partisipatif dan komunikasi yang diimplementasikan di Kecamatan Kadipaten Kabupaten Majalengka akan berdampak positif terhadap peningkatan kinerja pegawai.

4. Hasil uji hipotesis yang dilakukan menghasilkan bahwa kinerja pegawai mempunyai pengaruh terhadap kualitas pelayanan public. Artinya jika pegawai memiliki kinerja yang baik dan sesuai standar maka tingkat kinerja pegawai dalam kualitas pelayanan public akan baik pula, begitu juga sebaliknya apabila pegawai memiliki kinerja yang buruk maka kinerja pegawai dalam kualitas pelayanan public rendah. Penelitian ini menunjukkan bahwa pegawai menjadi suatu yang penting dalam mewujudkan kinerja pegawai dalam meningkatkan kualitas pelayanan public.

Berdasarkan data hasil penelitian mengenai pengaruh gaya kepemimpinan partisipatif dan disiplin kerja terhadap kinerja pegawai serta dampaknya pada kualitas pelayanan publik. Adapun saran yang dapat penulis berikan untuk pihakpihak yang berkepentingan yaitu:

1. Mengidentifikasi berbagai permasalahan yang dihadapi oleh Kecamatan Kadipaten Kabupaten Majalengka selama beberapa waktu tertentu, sehingga dapat melakukan perbaikan dan peningkatan kinerja pegawai di waktu yang akan datang.

2. Pada variabel kinerja pegawai skor terendah terdapat pada indicator pengetahuan pegawai. Merujuk kepada hal tersebut maka perlu dilakukan upaya peningkatan dalam merangsang kerja pegawai dengan memberikan motivasi dari pimpinan untuk terus mengembangkan kreativitas dan inovasi dalam bekerja, pemberian pengakuan bagi pegawai yang berprestasi, menjaga komunikasi antar pegawai, jaminan pekerjaan dan memberikan kesempatan untuk melanjutkan pendidikan yang lebih tinggi.

3. Pimpinan hendaknya lebih memperhatikan pegawai di dalam ataupun diluar jam kerja, yang dapat dilakukan dengan mengajak pegawai untuk berdiskusi secara pribadi baik mengenai pekerjaan atau masalah pribadi pegawai. Dengan adanya pendiskusian tersebut diharapkan pegawai merasa diperhatikan oleh atasan sehingga timbul kepuasan dalam bekerja.

4. Pimpinan harus lebih banyak memberi dukungan kepada pegawai dalam melaksanakan pekerjaannya dengan lebih bisa menciptakan lingkungan kerja yang nyaman agar pegawai termotivasi untuk melakukan pekerjaannya masing- 
masing, sehingga akan tercapai kinerja pegawai yang maksimal.

5. Bagi pegawai Kecamatan Kadipaten, kontribusi gaya kepemimpinan partisipatif dan komunikasi dalam meningkatkan kinerja pegawai dapat digunakan sebagai acuan untuk memperbaiki kinerja masing-masing pegawai.

6. Bagi peneliti mendatang hendaknya instrument penelitian lebih diperdalam dan dikembangkan lagi karena pada dasarnya masih banyak faktor-faktor lain yang mempengaruhi kualitas pelayanan publik, sehingga kemampuan mengukurnya lebih baik.

\section{DAFTAR PUSTAKA}

A.A. Anwar Prabu Mangkunegara, 2007, Manajemen Sumber Daya Manusia,. Cetakan Ke Tujuh PT. Remaja Rosdakarya, Bandung.

Adi, W. Gunawan, 2004. Genius Learning Strategy, Petunjuk praktis untuk menerapkan Accelerated Learning. Jakarta: Gramedia Pustaka

Akdon, dan Riduwan 2009. Aplikasi Statistika dan Metode Penelitian untuk. Administrasi dan Manajemen. Bandung: Dewa Ruci.

Arikunto, Suharsimi.1993. Prosedur Penelitian Suatu Pendekatan Praktek. Jakarta: Rineka Cipta.

Barsky, JD 1995. World - Class Customer Satisfaction , Richard D. Irwin, Inc.

Basri, A. F. M.,\& Rivai, V. 2005. Perfomance Appraisal. Jakarta:PT Raja Grafindo Persada.

Budi Winarno, 2005. Teori dan Proses Kebijakan Publik, Yogyakarta: Media Press.

Cheng, Lai dan Yeung.2008. The Driving forces of Customer loyalty:a study of internet service Providers in Hong Kong. International Journal of EBusiness Research, Volume 4, Issue 4 edited by In Lee; URLhttp://www.igi-global.com.
Dessler, Gary, 2000, Human Resource Management 8 th, New Jersey, Prentice Hall, Inc.

Duff, Angus, Xin Guo dan Mario Hair. 2008. Service quality measurement in the Chinese corporate banking market. International Journal of Bank Marketing Vol. 26 No. 5, 2008 pp. 305327 q Emerald Group Publishing Limited 0265-2323 DOI 10.1108/02652320810894389.

Dunn, William N, 2003. Pengantar Analisis Kebijakan Publik, Yogyakarta: Gadjah Mada University Press.

Dwijowijoto, Riant Nugroho. 2004. Kebijakan Publik Formulasi, Implementasi dan Evaluasi. Jakarta : PT Elex Media Komputindo Kelompok Gramedia.

Engle, LR \& Barnes, LM 2000. "Sales force automation usage, effectiveness, and cost- benefit in Germany, England and the United States", Journal of Business and Industrial Marketing , 154, 216-242.

Ferdinand

Augusty, 2002, Pengembangan Minat Beli Merek Ekstensi. Badan Penerbit Universitas Diponegoro, Semarang.

Gasperz, Vincent, 2002, Manajemen Kualitas dalam Praktek Bisnis Global, PT. Gramedia Pustaka Utama Jakarta.

Geyskens, I., Steenkamp, J.-B. E. M., and Kumar, N. 1999. A MetaAnalysis of Satisfaction in Marketing Channel Relationships, Journal of marketing Research 36 1999, pp 223-238.

Handayaningrat, Soewarno. 1994. Pengantar Studi Ilmu Administrasi dan Manajemen. Jakarta : CV.Haji Masagung.

Hariandja, Marihot T.E, 2002. Manajemen Sumber Daya Manusia. Jakarta: Grasindo.

Hasibuan, Malayu S.P. 2005. Manajemen Sumber Daya Manusia, Edisi Revisi. Bumi Aksara, Jakarta. 
Kirom, Bahrul. 2009. Mengukur Kinerja Pelayanan dan Kepuasan Konsumen. Reka Cipta : Bandung.

Kottler, Philip and Kevin Lane Keller. 2009. Marketing Management. 13th edition. New Jersey : Prentice Hall.

Mangkuprawira, Sjafri. 2007. Manajemen Mutu Sumber Daya Manusia. Bogor:Ghalia Indonesia.

Moh. Nazir, 1988, Metode Penelitian, Ghalia Indonesia.

Parasuraman,A.;Berry,Leonard

L.;Zeithaml,Valarie A. 2001. "Refinement and Reassessment of the SERVQUAL Scale", Journal of Retailing, 2001, 67, 4, 420-450.

Purnama, Nursya"bani. 2003. Analisis Pengaruh Sumber-Sumber Keunggulan Bersaing Bidang Pemasaran Terhadap Kinerja Perusahaan Manufaktur di Indonesia. JSB No. 8 Vol. 2.

Robbins, Stephen P, 2003. Perilaku Organisasi. Jakarta: PT Gramedia Pustaka Utama

Robbins. P.S.,2002, Prinsip-prinsip Perlaku Organisasi. Edisi kelima, Jakarta: PT Gramedia Pustaka Utama.

Robert L. Mathis \& John H. Jackson, 2007. Human Resources Management,. Edisi sepuluh, Penerbit Salemba Empat.

Sedarmayanti, 2007, Manajemen Sumber Daya Manusia, Penerbit Refika Aditama,

Sekaran, Uma. 2000. Metodelogi Penelitian. Penerbit Salemba Empat, Yogyakarta.

Silalahi, Ulber. 2009. Metode Penelitian Sosial. Bandung; PT. Refika Aditama.

Simpson, Eric, Phillip. 2006. Examining Employee Satisfaction, Customer Service And Customer Satisfaction In A Retail Banking Organization : Dissertation Prepared For The Degree Of Doctor Of Philosophy University Of North Texas.

Singarimbun, Masri \& Sofian Effendi, Metode Penelitian Survai, Penerbit. Pustaka LP3ES, Jakarta.
Sondang, P. Siagian. 2008, Manajemen Sumber Daya Manusia, Jakarta : Bumi. Aksara.

Stanton, William. J. 1992. Fundamentals of Marketing. Edisi Indonesia oleh Sadu Sundani. rlangga: Jakarta.

Sudjana. 1996 Teknik Analisis Regresi Dan Korelasi. Tarsito: Bandung.

Sugiyono, 2006, Statistika Untuk Penelitian, Cetakan Ketujuh, Bandung: CV. Alfabeta.

Syafeiie, Inu Kencana. 2003. Manajemen Pemerintahan. Jakarta : PT. Pertja.

Syafie, Inu Kencana. 1992. Pengantar Ilmu Pemerintahan. Jakarta : PT Eresco.

Tangkilisan. 2003 Kebijakan. Jakarta:Media Pesada.

Tjiptono, Fandi dan Gregorius Candra. 2005. Service, Quality, and Satisfaction. Andi Offset: Yogyakarta.

Wilkie, WL.1994. Consumer Behavior. 3 rd ed.. New York: John Wiley \& Son, Inc.

Yamit, Zulian. 2005. Manajemen Kualitas Produk dan Jasa. Edisi Pertama,cetakan keempat, Penerbit Ekonisia Kampus Fakultas Ekonomi UII Yogyakarta.

Zineldin, Mosad. 2007. Quality, innovation, differentiation QID management and competitiveness in the financial sector: a tool for overcoming financial and banking crises. Journal of Financial Transformation. School of Management and Economics, and Master in Psychology, Linnaeus University, Sweden. 


\section{BIOGRAFI PENULIS}

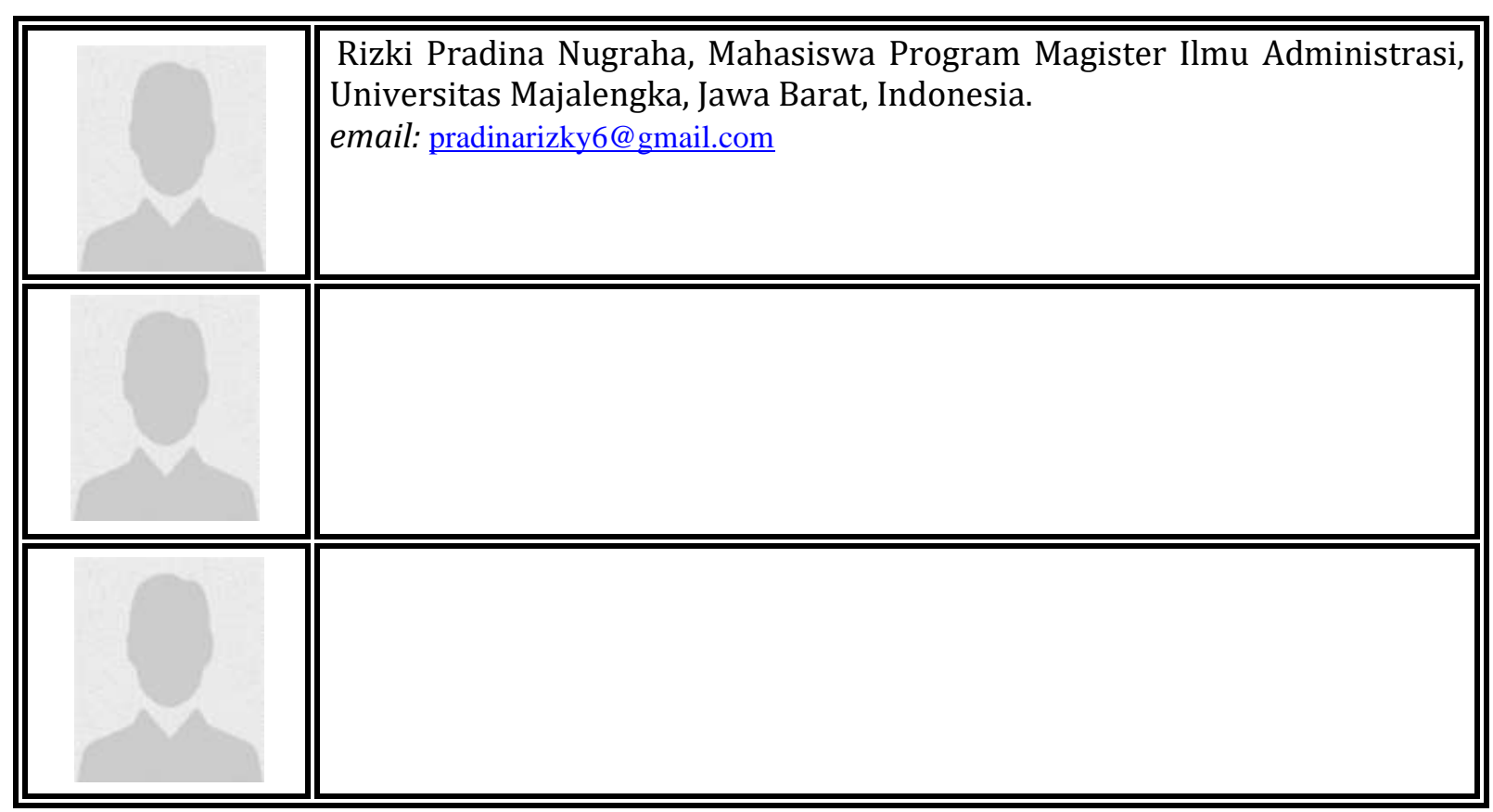

